\title{
EVOLUTION OF THE CONCEPT OF GOVERNABILITY IN THE CONTEXT OF DIGITALIZATION
}

\author{
Leonid V. Smorgunov, Kirill A. Neverov and Konstantin S. Kondratenko \\ Saint Petersburg State University \\ 7-9 Universitetskaya Emb., St Petersburg 199034, Russia
}

\begin{abstract}
New information technologies are used in public administration as part of the introduction of e-open government. Present paper focuses on the study of the centrality of governability for the digitization of public administration, affecting their architecture, processes and effects, including their social and political expression. Digital technologies generate not only hopes, but also challenges, and their distribution and use in public governance is associated with reasonable risks. Practical relevance to the project is given by the fact that at present digital technologies have become a common tool for the formation of a digital economy, society and government in Russia and in most countries of the world. The ontological basis of these findings is considered to be the phenomenon of socio-technical systems of power that are emerging in the process of the fourth technological (digital) revolution. The article traces the development of governance as base of governability, emphasizing nature of governability as a network effect of digitalization.
\end{abstract}

\section{KEYWORDS}

Digitalization, Governability, Network Effect

\section{INTRODUCTION}

New information technologies are used in public administration as part of the introduction of e-open government. Network technologies of distributed data (registers), which began to be used first in the financial sphere (2008), and then began to spread to the service sector, trade, public administration, art, etc., became a new and relevant step in advancing this issue. Meantime the social and political nature of this technology has not been studied. Moreover, the available studies reveal only certain aspects of the sociopolitical nature of digital technologies and are mainly descriptive and presumptive. The studies are dispersed between different branches of knowledge, which reduces their effectiveness given the humanitarian technical nature of the technology of distributed data. In this respect, the development of the fundamentals of the new synthesized scientific field of "digital social humanities" is significant. From this point of view, the formulated problem is relevant, since focuses the study of digital technology, taking into account its interdisciplinary nature, with a focus on the institutions of governing procedural processes. The subject of the paper and the formulated basic scientific problem are among the few that allow us to demonstrate the high potential of the integration synthesis of methodology and theory as a need for modern scientific knowledge focused on holism and complex thinking. The scientific relevance of the problem is also related to the fact that it focuses on the study of the centrality of governability for the digitization of public administration, affecting their architecture, processes and effects, including their social and political expression. Digital technologies generate not only hopes, but also challenges, and their distribution and use in public governance is associated with reasonable risks. In this regard, the relevance of the stated problem is expressed in combining scientific knowledge with critical thinking, which allows defining the limits of reasonable use of digital technologies in the interests of sustainable and dynamic development, as well as formulating the necessary algorithms to counter their irrelevant use in the public sphere. Practical relevance to the project is given by the fact that at present digital technologies have become a common tool for the formation of a digital economy, society and government in Russia and in most countries of the world. The Russian state program "Digital Economy", program documents of such international structures as the UN, the OECD, the World Economic Forum, the World Bank orient the modern sustainable development policy towards the prospects of the fourth 
technological revolution, which began with blockchain technologies. Consequently, the study of the political ontology of new digital formats of state governability is relevant from the standpoint of creating a scientific basis for evaluating and promoting the digitalization policy in public spheres and coordinating the world community in confronting grounded risks in this regard. So we stated following research question: could governability be a network effect of digitalization?

\section{THE CONCEPT OF GOVERNABILITY AND DIGITALIZATION}

The concepts of governability over the past three decades have evolved under the influence of new information and communication technologies. ICTs of the first, second and third generations defined state governability from functional (electronic public services), organizational (electronic participation) and communicative (monitoring democracy) positions. The network theory of public administration has formed a radical concept of "governance without government". The fourth generation of ICT has developed a distributed database technology (registers), a blockchain based on the ability to perform direct transactions between users of distributed networks based on cryptographic protocols and algorithms, almost without trust and bypassing third parties, including the state (Antonopulos 2014; Swan 2015). Blockchain was also examined for administrative purposes, its challenges, risks and limitations (Cusumano 2014; Shermin 2017; Danaher et al. 2017; Scott, Loonam, Kumar 2017). Primary studies of ontological issues of digitalization (philosophical, political, sociological) formed the idea of transition from institutional-rigid governance architecture with a stable representation and hierarchy (centralism) to institutional and procedural, based on a humanitarian-technical platform of network cooperation with free identification, organized anarchy and distributed knowledge. In this regard, the question is raised whether digital technologies are a complex system with non-linear connections that create difficulties for the algorithmic and institutionalization of governance and action in it, or can we talk about complex, algorithmic, but institutionalized digital governance. Along with the optimistic position regarding the political, social and technological performance of digital technologies, there is a reasonable judgment about the risks and challenges for society associated with the deinstitutionalization of interactions, instability and imbalance in the development of public life, the use of crime and terrorism. One of the central issues in the optimistic and critical areas is the lack of clarity regarding the new nature of the organization, and therefore governance and governability in distributed networks and digital platforms, including their use in the public sphere. Often this is described by the opposition of two political strategies related to the digitalization of public administration: "digitalization of politics" vs "politics of digitalization". The first direction relates to incremental, adaptive policy strategies for introducing digital technologies into politics and public administration. At the same time, digital technologies are not considered to invade the nature of the political, but are merely a technological means of increasing the level of efficiency in the execution of functions. The second direction is a more radical, proactive strategy for introducing digital technologies based on the identification and use of their institutional-procedural political properties and capabilities. In this case, there are many assessments of their properties - from the substantiation of the anarchist nature of digital technologies to allegations of their internal focus on new forms of political control, domination and subordination (neoliberal, republican and foucaudian criticism of digitalization). The ontological basis of these findings is considered to be the phenomenon of socio-technical systems of power that are emerging in the process of the fourth technological (digital) revolution.

\section{NETWORK DEVELOPMENT OF GOVERNANCE AS BASE FOR GOVERNABILITY}

The concepts The phenomenon of governability is closely related to the concept of governance, which, despite its popularity in the social sciences, is rather blurred in the subject field. To summarize, the following aspects can be distinguished as they follows.

Political governance, by which we mean not only public administration, but also, in a broader sense, governance of policy making and implementation processes - public policy, public affairs (Rhodes, 1996). Of particular importance are works that describe the signs of state governability arising on the basis of various models of public administration - scientific management, new public management, management of public 
values (Cass, Vigoda-Gadot E., 2009; Stoker G., 2010; Kooiman J., 2010; Kooiman J., 2010; Lynn L., Jr., Robichau R. W., 2013; Smorgunov L.V., 2012; Swanson D, Bizikova L., 2014).

The transformation of this category is traced in the works of J. Habermas, who, in fact, emphasized the governability of society through the development of communication, dialogue and cooperation in society. In modern Russian studies, the problem of governability is considered in this context. Among the works of domestic authors can distinguish research by Rubtsova M.V., engaged in identifying the relationship of governability with the self-organization of society, uncertainty and power (including the value aspect of governability), (Rubtsova M.V., 2010). In papers of Kupryashina G.L., Gritskevich T.I. manageability serves as a criterion for the success of the strategy of administrative reforms and public administration as a whole, since it generally reflects the realization of the management capacity of state structures (Kupryashin, 2011; Gritskevich, 2007).

The key role in the study of governability is played by the development of governance networks and policy networks that arise in connection with the allocation of resources, the growing influence of non-state actors on decision-making processes and, consequently, the decline in the role of the state as a key political actor. In this context, members of the research team developed the concept of a "coordinating state", the main idea of which is that the authorities in the new conditions, although they retain a central role in the processes of policy development and implementation, but increasingly perform the function of coordinating network interactions (Börzel, 1998; Koliba, Meek, Zia, 2011;Klijn, Edelenbos, 2012). In the context of the development of globalization based on network governance, a belief arises about the possibility of the existence of a "governance without government" (Rosenau, Czempel, 1992; Peters, 1998). M. Castells called modern society network, but today there are works that suggest that as a result of the fourth industrial revolution (Schwab, 2016). Of course, horizontal ties continue to dominate, but they are becoming less stable. Relationships become discrete in time, and the period of their existence is rapidly decreasing. Why capitalize on your social or institutional ties if modern technologies allow them to be established very quickly? In addition, there is a limit to the glut of bonds, since it is impossible for both individuals and institutions to maintain a large number of relationships equally effectively. Challenges of governability in this aspect are not of a subjective nature, as is the case with political governance, where challenges are facing the state, but rather relate to the governability of society as a self-organizing system.

The study of distributed networks contributed to the formation of a whole scientific field related to the study of the socio-political nature of digitalization (Berry, David, 2014; Floridi, 2015; Cormier, 2016; Carolan, 2018). In the center of this direction is the interaction of the three main critical waves - neoliberal, republican and foucaudian. There is still no integrated vision of the nature of digital technology as a socio-technical system. The concept of algorithmic public administration has been characterized by the technocratic basis of the description and contains a number of contradictions in the description of the possibility of governability, based algorithms in the public domain. In this regard, digital public administration requires its own social and political substantiation (Arkhipova, 2016; Digital Government - 2020: Prospect for Russia, World Bank, 2016; Ayad Al-Ani, 2017; IGI Global, 2015; O'Reilly, 2011; Margetts \& Dunleavy, 2013).

In connection with the development of the network governance methodology, the study of the practice of introducing new information technologies based on Web 1.0, 2.0 and 3.0 is becoming increasingly important. The concept of e-government has been developing actively since the late 1990s. The idea of actively using new information and communication technologies (ICT) to increase the effectiveness of government activity emerged during the implementation of administrative reforms based on the ideology of New Public Management, which began to be carried out in Western countries (primarily Anglo-Saxon) in the early 1990s. The term itself is electronic government (e-government), however, it appears later in 1997 on the initiative of the National Science Foundation of the USA. The concepts of public governance over the past three decades have evolved under the influence of new information and communication technologies. ICTs of the first, second, and third generations have defined functional governability of government (Schedler, Summermatter, 2007), organizational (Evans, Yen, 2006; King, 2012; Bovaird, Loffler, 2012) and communicative (Chadwick, 2003). Of particular importance when studying e-government is the question of its openness and new technologies for using information and knowledge. Network electronic technologies are considered as the most appropriate structures for receiving, transmitting and diffusing knowledge, which significantly reduces management costs, transaction costs of interaction and increases the overall level of governability in organizations and in the public sphere (Milner, 2000; Barquin, 2001; Bellamy, 2002; Tsoukas, 2005). 


\section{CONCLUSION}

The main contribution of this article was an examining of the concept of governability effected by vast and swift development of information and communication technologies in the past few years. It's showed changing attitude towards governability emphasizing the uncertainty of the political-institutional nature of digital technologies and the selection of relevant designs for their compatibility with government, ensuring the governability of the public sphere in the context of the contemporary technological revolution. The concepts of governability over the past three decades have evolved under the influence of new information and communication technologies. ICTs of the first, second and third generations defined state governability from functional (electronic public services), organizational (electronic participation) and communicative (monitoring democracy) positions. The network theory of public administration has formed a radical concept of "governance without government". The fourth generation of ICT has developed a distributed database technology (registers), a blockchain based on the ability to perform direct transactions between users of distributed networks based on cryptographic protocols and algorithms, almost without trust and bypassing third parties, including the state. However, digital technologies are not considered to invade the nature of the political, but are merely a technological means of increasing the level of efficiency in the execution of functions. We started from governance as a core concept for the following consideration of what governability in context of digitalization is. Then we studied the development of governance networks and institutions and policy networks that arise in connection with the allocation of resources, the growing influence of non-state actors on decision-making processes and, consequently, the decline in the role of the state as a key actor politicians. Challenges of governability in this aspect are not of a subjective nature, as is the case with political governance, where challenges are facing the state, but rather relate to the governability of society as a self-organizing system. In the fin of our paper we focused on the study of the practice of introducing new information technologies based on Web 1.0, 2.0 and 3.0 is becoming increasingly important, pushed forward by connection with the development of the network governance methodology.

\section{ACKNOWLEDGMENT}

The author disclosed receipt of the following financial support for the research, authorship, and/or publication of this article: This work was supported with a grant from the Russian Science Foundation (grant 19-18-00210 "Political ontology of digitalization: Study of institutional bases for digital forms of governability").

\section{REFERENCES}

Antonopulos, A., 2014. Mastering Bitcoin: Unlocking Digital Crypto-Currencies. Sebastopol, Ca.;

Arkhipova, Z. V., 2016. Transformation of "e-Government" into "Digital Government". In Proceedings of Baikal State University, Vol.26, No.5, pp. 818-824;

Ayad, Al-Ani, 2017. Government Platform: Services, Participation and Policies', in Friedrichsen, M. and Kamalipour, Y. (eds.) Digital Transformation Journalism and News Media. Cham: Springer, pp. 179-196;

Berry, D. M., 2014. Critical Theory and the Digital. New York: Bloomsbury;

Börzel, T.A., 1998. Organizing Babylon : On the Different Conceptions of Policy Networks. In Public Administration, Vol.76,No.2, pp.253-273;

Bovaird, T. and Loffler, E., 2012. From Engagement to Co-production, in Pestoff, V. et al. New Public Governance, the Third Sector and Co-production. New York and London: Routledge, pp. 35-60;

Carolan, M., 2018. 'Smart' Farming Techniques as Political Ontology: Acceleration of the Neoliberal and Not-So-Neoliberal Worlds'. In Sociologia Ruralis, Vol.58, No.4, pp. 745-764.

Cass, Vigoda-Gadot E., 2009. Building Strong State. Improving Governance and Public Management. Farnham: Ashgate Publishing Company;

Cormier, R., 2016. Basic Cable: Notes: Toward Digital Ontology. PhD dissertation;

Cusumano, M., 2014. Technology Strategy and Management: the Bitcoin Ecosystem. In Communication of the ACM, Vol.57, No.10, pp. 22-24. 
Danaher J. et al, 2017. Algorithmic Governance: Developing a Research Agenda Through the Power of Collective Intelligence. In Big Data \& Society, Vol.4, No.2, pp. 1-21;

World Bank, 2016. Digital Government - 2020: Prospect for Russia;

Floridi, L., 2015. The Onlife Manifesto: Being Human in a Hyperconnected Era. Springer;

Gritskevich, T. I., 2007. Modern Reforms: Manageability and Epistemological Uncertainty. In Bulletin of Novosibirsk State University, Series: Philosophy, Vol.5, No.1, pp. 60-64;

IGI Global, 2015;

King Ch., Cruickshank M., 2012. Building Capacity to Engage. In Community Development Journal, Vol.47, No.1, pp. 5-28;

Klijn E.H., Edelenbos J., 2012. The Influence of Democratic Legitimacy on Governance Networks. In Administration \& Society, Vol.45, No.6, pp. 627-650;

Koliba, Ch. et al, 2011. Governance Networks in Public Administration a nd Public Policy. Roka Raton, London, New York: CRC Press;

Kooiman, J., 2010. Governing as Governance. London et all: Sage;

Kupryashin, G.L., 2011. Modernization and Governability. In Moscow University Bulletin. Series 21: Governance (state and society), Vol. 2, pp. 67-86;

Lynn, L., Jr., Robichau, R. W., 2013. Governance and Organizational Effectiveness: Towards the Theory of Government Performance. In Journal of Public Policy, Vol.33, No.2, pp. 201-228;

Margetts, H. and Dunleavy, P., 2013. The Second Wave of Digital-Era Governance: a Quasi-Paradigm for Government on the Web. In Philosophical Translations of the Royal Society A, Vol.371, pp.1-17;

O'Reilly, T., 2011. Government as a Platform. In Innovations, Vol.6, No.1, pp. 13-40;

Peters, G., 1998. Governance without Governme: Rethinking Public Administration. In Journal of Public Administration, Research and Theory, Vol.8, No.2, pp. 227-243;

Rhodes, R.A.W. 1996. The New Governance: Governing without Government. In Political Studies, Vol.44, No.4, pp. 652-667;

Rosenau, J. and Czempel, E.-O., 1992. Governance without Government: Politics. Cambridge: Cambridge University Press;

Rubtsova, M.V., 2010. Conceptual Foundations of the Study of the Phenomenon of Controllability in Sociology of Management. SPb .: Book House;

Schedler, K., Summermatter, L.2007. Customer Orientation: Motives and Effects. In Government Information Quarterly, Vol.24, No.2, pp. 291-311;

Schwab, K., 2016. The Fourth Industrial Revolution. World Economic Forum.

Scott, B. et al, 2017. Exploring the Rise of Blockchain Technology: Towards Distributed Collaborative Organizations. In Strategic Change, Vol.26, No.5, pp.423-428. https://doi.org/10.1002/jsc.2142;

Shermin, V., 2017. Disrupting Governance with Blockchains and Smart Contracts. In Strategic Change, Vol.26, No.5, pp. 499-509;

Smorgunov, L.V., 2012. In Search of Governability: Concepts and Transformations of Public Administration in the 21st Century. SPb .: Ed. St. Petersburg University;

Stoker, G., 2010. Governance Theory: A Cross-Disciplinary Approach. Basingstoke: Palgrave;

Swan, M. 2015. Blockchain. Sebastopol, Ca.: O'Reilly Media.

Swanson, D., Bizikova, L., 2014. Thrift Ch. and Governors of the Nexus of Sustainability, Accountability and Adaptability. Manitoba: IIPG. 